\title{
Health complaints and immunological markers of exposure to bioaerosols among biowaste collectors and compost workers
}

Jürgen Bünger, Michael Antlauf-Lammers, Thomas G Schulz, Götz A Westphal, Michael M Müller, Peter Ruhnau, Ernst Hallier

\begin{abstract}
Objectives-In a cross sectional study, work related health complaints and diseases of 58 compost workers and 53 biowaste collectors were investigated and compared with 40 control subjects. Levels of specific IgG antibodies to moulds and bacteria were measured as immunological markers of exposure to bioaerosols.

Methods-With a standardised protocol, the participants of the study were interviewed for work related symptoms, conditions of exposure to bioaerosols at their workplaces, exposure to bioaerosols from other sources, atopic diseases, and smoking habits. They were clinically examined by physicians specialised in occupational medicine. Also, concentrations of specific IgG antibodies against antigens of moulds and actinomycetes occurring regularly at these workplaces were measured and compared with the health complaints of the workers.
\end{abstract}

Results-Compost workers had significantly more symptoms and diseases of the airways $(p=0.003)$ and the skin $(p=0.02)$ than the control subjects. Health complaints of biowaste collectors did not differ significantly from those of the control group. Subjects with atopic diseases were underrepresented in the compost workers $(p=0.003)$. Significantly increased antibody concentrations against fungi and actinomycetes were measured in workers at composting plants. The concentrations in biowaste collectors did not differ significantly from those in the control subjects. A significant association between the diseases and increased antibody concentrations were found in the compost workers.

Conclusion-The high exposure to bioaerosols of compost workers is significantly associated with a higher frequency of health complaints and diseases as well as higher concentrations of specific antibodies against moulds and actinomycetes. A healthy worker effect is indicated by the

Accepted 17 March 2000 underrepresentation of atopic diseases among the compost workers compared with biowaste collectors and the control group.

(Occup Environ Med 2000;57:458-464)

Keywords: exposure to bioaerosols; organic dust; IgG antibodies; moulds; actinomycetes

Filamentous fungi (moulds) and bacteria grow in biowaste or on biologically contaminated waste. When these materials are handled, airborne microorganisms and spores are emitted into the air as inhalable organic dust or bioaerosols. ${ }^{1}$ These terms are often used synonymously. Concentrations of $10^{7}$ colony forming units per $\mathrm{m}^{3}$ air $\left(\mathrm{cfu} / \mathrm{m}^{3}\right)$ of airborne microorganisms have regularly been measured in composting facilities, whereas exposures of biowaste collectors were in the range of $10^{5}$ $\mathrm{cfu} / \mathrm{m}^{3}$ air.

EXPOSURE TO BIOAEROSOLS IN WASTE TREATMENT INDUSTRIES

In 1993 a German multicentre study was conducted, which identified hundreds of different species of moulds and saprophytic bacteria, including thermophilic actinomycetes, in the air of waste treatment plants. ${ }^{2-4}$ Also, low concentrations of pathogenic bacteria ${ }^{2}$ and viruses ${ }^{5}$ were identified. Exposures of biowaste collectors were substantially lower in recently published studies. ${ }^{67}$ Table 1 summarises the study results and reference measurements. ${ }^{2-8}$

In most studies, exposure to bioaerosols was estimated by measuring culturable microorganisms $\left(\mathrm{cfu} / \mathrm{m}^{3}\right)$. However, this procedure includes only viable microorganisms, whereas the total count of viable and non-viable cells measured by scanning electron microscopy or fluorescence microscopy is much higher. ${ }^{69}$ These non-viable microorganisms can contribute to health risks from toxic or immunopathogenic effects.

HEALTH EFFECTS OF BIOAEROSOLS FROM WASTE TREATMENT INDUSTRIES

The primary effect of exposure to bioaerosols is often an inflammatory response of the upper airways with congested nose, sore throat, and dry cough often in connection with symptoms of the eyes like redness and tears (mucous membrane irritation), subsiding several hours after the end of exposure. ${ }^{10-12}$ 
Toxicoses

Bioaerosols are capable of inducing severe toxic reactions such as the organic dust toxic syndrome, also called toxic pneumonitis. ${ }^{10}{ }^{13}$ Endotoxins from gram negative bacteria were identified as a cause of these toxic symptoms and were also associated with acute $e^{14-16}$ and chronic $^{17}{ }^{18}$ impairment of lung function.

\section{Infections}

Increased health risks due to exposure to bioaerosols, mainly infections of the upper air ways and the skin, were reported in workers sorting waste. ${ }^{19}{ }^{20}$ Dermatological and respiratory symptoms, including infections, were also found in a study on landfill employees in New York. ${ }^{21}$

\section{Allergies}

Allergens of moulds can trigger type I allergies - such as bronchial asthma and allergic rhinitis-in people predisposed to atopic diseases. ${ }^{13}$ Induction of extrinsic asthma was reported in workers sorting waste. ${ }^{22}$ Antigens of fungi and actinomycetes can also cause type III allergy-namely, extrinsic allergic alveolitis -which is also called hypersensitivity pneumonitis. Cases of extrinsic allergic alveolitis in workers handling compost have been reported in Belgium ${ }^{23}$ and the United States. ${ }^{24}{ }^{25}$ One case of a waste collector with simultaneous symptoms of allergic bronchopulmonary aspergillosis and extrinsic allergic alveolitis was described in Germany. ${ }^{26}$ Increased concentrations of IgG antibodies specific to the responsible agents are often found in patients with extrinsic allergic alveolitis, as well as in many symptomless people with high exposures to the antigens of moulds and actinomycetes. ${ }^{27-31}$

The objectives of the study were the examination of compost workers and biowaste collectors for health effects related to exposure to bioaerosols, the exploration of specific IgG concentrations to moulds and actinomycetes as immunological markers of exposure to bioaerosols, and a possible association with the symptoms and diseases of the waste workers.

\section{Material and methods}

The study was performed in the city of Hamburg and in seven small towns throughout Germany from 1996 to 1998 . The investigations were performed in the months from July to September of each year.

HANDLING AND TREATMENT OF BIOWASTE Biowaste was collected from private households (kerbside collection) on a 2 week schedule, and to a minor extent from other sources such as food or fodder processing plants and restaurants. The contents of bins and containers from 110 litres up to 600 litres were dropped into rear loading compactor lorries by hydraulic lifters. The biowaste was transported to composting plants and dumped into bunkers for further processing.

At the composting plants non-compostable materials were removed by manual sorting. The biowaste was mixed with shredded garden waste or hay and straw and piled up in rows by shovel loaders or specially designed vehicles. After the biodegradation process and before delivery, the compost was sieved to exclude non-biological compounds which had not been removed during manual sorting.

\section{STUDY PARTICIPANTS}

A total of one female and 151 male full time employees participated in the study. They answered occupational, environmental, and symptom orientated questions in a brief standardised interview performed on the occasion of a preventive physical examination. Work related symptoms in the previous 30 days were registered. The workers were interviewed and examined by physicians specialised in occupational medicine. Diagnoses were coded according to the international classification of diseases, 9th revision, clinical modification (ICD9-CM) when possible. ${ }^{32}$ Serum samples for measurement of specific IgG antibodies were taken on the same occasion.

Sixteen compost workers and 24 biowaste collectors who were newly employed in the investigated workplaces served as control subjects. They answered the questionnaire and were examined before taking up the occupation or within the first 3 weeks of employment. The female worker who was employed at a composting plant was excluded from evaluation for statistical reasons. The resulting 151 data sets, including 58 compost workers, 53 biowaste collectors, and 40 control subjects, were processed and analysed further.

\section{MEASUREMENT OF SPECIFIC ANTIBODIES}

Serum concentrations of specific IgG antibodies to antigens of seven moulds and four actinomycetes were measured as immunological markers of exposure in 111 waste handling workers and 40 controls, with an indirect immunofluorescence test (IIFT) and an enzyme linked immunosorbent assay (ELISA).

After taxonomic verification of the species, antigens were prepared from pure cultures of fungi and actinomycetes which were identified in the air at compost plants in the German multicentre study. The IIFT and ELISA were developed with these antigen preparations as purified and standardised antigens of most microorganisms were not available from commercial suppliers. ${ }^{33} 34$ As serum samples of waste workers with known extrinsic allergic alveolitis could not be obtained, positive reactions of the antigen preparations were evaluated with serum samples from five farmers with extrinsic allergic alveolitis. The serum samples which were tested positive with the prepared antigen solutions were pooled and used as positive controls for the ELISA and the IIFT. Chemicals for buffers and compounds not otherwise specified were obtained from Merck (Darmstadt, Germany) and Riedel-de Haën (Seelze, Germany).

\section{Indirect immunofluorescence test (IIFT)}

The IIFT was shown previously to be a useful method for the measurement of specific IgG especially against cell wall antigens of moulds. ${ }^{35}{ }^{36}$ The IIFT technique was chosen 
due to its higher sensitivity compared with an ELISA technique based on the soluble antigen fractions of the same moulds. ${ }^{33}$ The following fungi were included: Aspergillus fumigatus, Aspergillus nidulans, Aspergillus niger, Aspergillus versicolor, Penicillium brevicompactum, Penicillium crustosum. They were predominant in air samples from these workplaces. Aspergillus sydowii was identified in low concentrations $\left(<10^{3} \mathrm{cfu} / \mathrm{m}^{3}\right)$ at several of the plants investigated. This fungus was used for testing of cross reactions with specific IgG of the other aspergillus species. A detailed description of the preparation of fungal antigens and the IIFT antibody determination has recently been published. $^{34}$

Briefly, the procedure involves the separation of mycelia and spores of moulds from pure cultures grown on malt extract agar plates (Difco Laboratories, Detroit, MI, USA); the resulting antigen solution was lyophilised and stored at $-20^{\circ} \mathrm{C}$ until use. For IIFT the dried material was redissolved in phosphate buffered saline (PBS, pH 7.3), treated with a microdisperser (Ultra Turrax, Braun, Melsungen, Germany), and diluted to a concentration of about 10 $\mu \mathrm{g} / \mathrm{ml}$ with PBS, resulting in a homogenous monolayer of fungal material on the microscopy slides.

The antigen solution $(20 \mu \mathrm{l})$ was pipetted onto specially prepared microscopy slides (bioMérieux, Marcy-l'Etoile, France) and dried for 2-3 hours. Serum samples were log 4 diluted with PBS to concentrations up to 1:1024 and also applied to the slides, which were incubated for 30 minutes at $37^{\circ} \mathrm{C}$. After three washing procedures, each slide was stained with Evans blue (1\%, bioMérieux) and specific IgG was detected with a fluorescein labelled goat antihuman IgG (Fluoline G, bioMérieux). All examinations were performed by the same laboratory technician and confirmed independently by a second investigator. The highest dilution of each serum sample which gave definite cell wall fluorescence was taken as the end point. Concentrations of 1:1024 were considered positive, and higher dilutions were prepared and investigated likewise.

Enzyme linked immunosorbent assay (ELISA)

The ELISA was developed by Engvall and Perlmann ${ }^{37}$ and is routinely used to detect specific antibodies to soluble antigens of actinomycetes. ${ }^{38}$ Predominant species of actinomycetes were: Saccharopolyspora rectivirgula (formerly named Micropolyspora faeni), Saccharopolyspora hirsuta, Saccharomonospora viridis, Streptomyces thermovulgaris. A detailed description of the preparation of actinomycete antigens and the antibody measurement with ELISA has been published previously. ${ }^{33}$

Briefly, the procedure involves growing of liquid cultures of actinomycetes in synthetic broth AOAC (Difco Laboratories, Detroit, MI, USA) at $37^{\circ} \mathrm{C}$ (Saccharopolyspora hirsuta, Streptomyces thermovulgaris) or $50^{\circ} \mathrm{C}$ (Saccharopolyspora rectivirgula, Saccharomonospora viridis) for 14 days; then soluble antigens were derived by ultrasonication and centrifugation of the cul- tures. The supernatant was dialysed against double distilled water for 24 hours to remove nutrient media and low molecular weight components. Antigens of Streptomyces thermovulgaris were prepared with the double dialysis method of Edwards, ${ }^{39}$ modified by Treuhaft et $a .^{40}$

Flat bottomed 96 well microtitre plates (Maxisorp F96, Nunc, Denmark) were coated with these antigens at concentrations of 8-20 $\mu \mathrm{g} / \mathrm{ml}$ and incubated overnight at $4^{\circ} \mathrm{C}$. After washing and blocking, the plates were dried and stored at $-20^{\circ} \mathrm{C}$ until use. For the assay $100 \mu \mathrm{l}$ serum diluted 1:800 with PBS was pipetted to each well of the microtitre plates. Controls for unspecific binding (PBS), as well as negative and a pooled positive serum were tested with each microtitre plate. After incubation for 1 hour at $37^{\circ} \mathrm{C}$ the plates were washed three times, and $100 \mu \mathrm{l}$ PBS containing $0.1 \%$ peroxidase coupled antihuman IgG (Organon Teknika) was added. The plates were incubated again for 1 hour at $37^{\circ} \mathrm{C}$ and washed three times. Then $100 \mu \mathrm{l}$ of the substrate buffer containing $0.2 \%$ ABTS (2,2-azino-di-(3-ethylbenzthiazoline-6-sulfonate)) (Boehringer, Mannheim, Germany) and $0.2 \% \mathrm{H}_{2} \mathrm{O}_{2}$ were added. After an incubation of 30 minutes at $37^{\circ} \mathrm{C}$, the optical density of each well was measured with a microtitre plate reader (Spectra, SLT Instruments, Crailsheim, Germany). All samples were analysed in duplicate and measurements were repeated within one week. The variation coefficients within the day were regularly below $20 \%$. However, results from week to week varied up to $50 \%$ at maximum. All measurements with coefficients of variation of $>20 \%$ were repeated. Values were expressed as means and corrected for differences between control measurements of the singular microtitre plates. Antibody concentrations exceeding 3 SDs of the mean were considered to be high.

\section{STATISTICS}

Data were stored with Access 97 (Microsoft, Seattle, USA); descriptive and analytical calculations were performed with Statistica 5.1 (StatSoft, Hamburg, Germany). Graphs were drawn with Statview 4.57 (Abacus Concepts Berkeley, USA) and Excel 97 (Microsoft). The differences between variables from compost workers, biowaste collectors, and controls were analysed with unpaired $t$ test, Fisher's exact test, and Kruskal Wallis test where appropriate. No correction was performed for the confounding effects of smoking as there was no significant difference in smoking habits between the three groups and an exclusion of the smokers ( $>55 \%$ of all workers in each group) would have lowered the statistical power of the study greatly.

\section{Results}

The biowaste collectors were significantly younger than the compost workers and had a significantly shorter duration of employment. The mean duration of employment for compost workers was 3 years, whereas biowaste collectors had been employed for only 1.5 years. About $13 \%$ of all workers had previous 
Table 2 Demographic characteristics and confounding variables of biowaste collectors, compost workers, and control subjects

\begin{tabular}{|c|c|c|c|c|c|c|c|c|}
\hline \multirow[b]{2}{*}{ Group $(n=)$} & \multicolumn{2}{|l|}{ Age (y) } & \multicolumn{2}{|c|}{ Exposure (months) } & \multirow{2}{*}{$\begin{array}{l}\text { Workers with } \\
\text { confounding } \\
\text { exposures }\end{array}$} & \multicolumn{3}{|c|}{ Smoking habits } \\
\hline & Mean (SD) & (Range) & Mean (SD) & (Range) & & Never & Former & Current \\
\hline Biowaste (53) & $33(6)^{\star \star}$ & $(21-50)$ & $18(22)$ & $(2-126)$ & 5 & 9 & 9 & 35 \\
\hline Compost (58) & $40(11)$ & $(19-59)$ & $37(26)^{\star \star \star}$ & $(4-112)$ & 7 & 15 & 10 & 33 \\
\hline Control (40) & $38(11)$ & $(20-61)$ & $0.4(0.3)$ & $(0-1)$ & 7 & 10 & 4 & 26 \\
\hline
\end{tabular}

${ }^{\star \star} \mathrm{p}<0.01 v$ both other groups with unpaired $t$ test: ${ }^{\star \star \star} \mathrm{p}<0.001 v$ biowaste collectors with unpaired $t$ test.

exposure to bioaerosols from farming and working in buildings with cattle, swine, or poultry. One compost worker had simultaneous exposure from working on his own farm in the evenings. Non-significantly fewer biowaste workers than workers from the other groups were exposed to bioaerosols from these sources. The number of current smokers was high compared with data from population based studies in Europe, but there was no significant difference between the three groups. An overview of the group characteristics and confounding factors is given in table 2 .

According to the physical examinations, 22 compost workers had up to three health complaints compared with only three biowaste collectors, and one control subject (table 3). Compost workers had a significantly higher prevalence of tracheobronchitis. Mucous membrane irritation, sinusitis, eczema, dermatomycosis, pyoderma, and otitis externa were also diagnosed more often in the compost workers, but these singular results were not significant when compared with the control group. One compost worker complained of typical symptoms of organic dust toxic syndrome. The health complaints of biowaste collectors did not differ significantly from those of the control group. Severe infections were not found, and no cases of extrinsic allergic alveolitis or asthma were reported.

Table 3 Diseases of the airways and the skin in the waste workers, diagnosed by occupational health physicians (in workers with $>1$ disease only the leading disease was considered)

\begin{tabular}{|c|c|c|c|c|}
\hline \multirow[b]{2}{*}{ Mucous membrane irritation } & \multirow{2}{*}{$\begin{array}{l}\text { Biowaste } \\
\text { collectors } n=53\end{array}$} & \multicolumn{2}{|c|}{$\begin{array}{l}\text { Compost workers } \\
n=58\end{array}$} & \multirow{2}{*}{$\begin{array}{l}\text { Control } \\
\text { subjects } n=40 \\
0\end{array}$} \\
\hline & & 2 & & \\
\hline Tracheobronchitis $(490.0)$ & 2 & 7 & $\mathrm{p}=0.04$ & 0 \\
\hline Sinusitis $(473.0-473.3)$ & 1 & 4 & & 1 \\
\hline Organic dust toxic syndrome & 0 & 1 & & 0 \\
\hline Diseases of the airways (combined) & 3 & 14 & $\mathrm{p}=0.003$ & 1 \\
\hline Eczema (692.9) & 0 & 3 & & 0 \\
\hline Dermatomycosis (111.9) & 0 & 2 & & 0 \\
\hline Pyoderma $(586.0)$ & 0 & 1 & & 0 \\
\hline Otitis externa $(380.1)$ & 0 & 2 & & 0 \\
\hline Diseases of the skin (combined) & 0 & 8 & $\mathrm{p}=0.02$ & 0 \\
\hline Total diseases & 3 & 22 & $\mathrm{p}<0.0001$ & \\
\hline
\end{tabular}

$\mathrm{p}$ Values are calculated $v$ the control group with Fisher's exact test, two sided.

Table 4 Gastrointestinal symptoms and atopic diseases of waste workers and their families as reported by the workers

\begin{tabular}{|c|c|c|c|}
\hline & $\begin{array}{l}\text { Biowaste collectors } \\
n=53\end{array}$ & $\begin{array}{l}\text { Compost workers } \\
n=58\end{array}$ & $\begin{array}{l}\text { Control subjects } \\
n=40\end{array}$ \\
\hline Nausea (787.01) & 0 & $\mathrm{p}=0.14$ & 0 \\
\hline Vomiting (787.03) & 0 & 0 & 0 \\
\hline Diarrhoea (787.9) & 0 & 0 & 0 \\
\hline $\begin{array}{l}\text { Gastrointestinal symptoms } \\
\text { (combined) }\end{array}$ & 0 & $\mathrm{p}=0.14$ & 0 \\
\hline Rhinitis allergica (477.9) & 14 & $\mathrm{p}=0.003$ & 10 \\
\hline Extrinsic asthma (493.0) & 1 & 0 & 0 \\
\hline Atopic diseases in family & 16 & $\mathrm{p}=0.05$ & 8 \\
\hline
\end{tabular}

$\mathrm{p}$ Values are calculated $v$ the control group with Fisher's exact test, two sided.
Four compost workers reported nausea in the questionnaire whereas no member of the other groups complained of gastrointestinal symptoms. Also, compost workers had a significantly lower prevalence of allergic rhinitis than biowaste collectors and the control subjects. The prevalence of atopic diseases was also significantly lower in the families of the compost workers (table 4).

Measurable IgG antibody concentrations were found in over $95 \%$ of both the employees and the control group. Significantly higher antibody concentrations to Aspergillus fumigatus were measured in workers at composting plants, whereas antibody concentrations of the biowaste collectors were not higher than those of the control subjects (fig 1). When the six other fungal antigens were tested, compost workers also had higher titres in each singular test compared with biowaste collectors and control subjects $(p<0.001$ in Kruskal Wallis test for each). Significantly increased antibody concentrations were also obtained for actinomycetes Saccharopolyspora rectivirgula and Streptomyces thermovulgaris in the compost workers (fig 2). The concentrations for Saccharopolyspora hirsuta were increased as well ( $<<0.001$ in Kruskal Wallis test), whereas Saccharomonospora viridis showed no significant difference.

Twenty compost workers had one or several increased antibody concentrations, compared with only three biowaste collectors and one subject of the control group. There was a significant association between diagnosed diseases and increased IgG antibodies in the compost workers (table 5). After exclusion of the compost workers with confounding exposure to bioaerosols (three workers with disease and four workers without) the results were still significant (table 6). No such association was found for the biowaste collectors. Two biowaste collectors and the control subject with increased specific IgG had earlier confounding

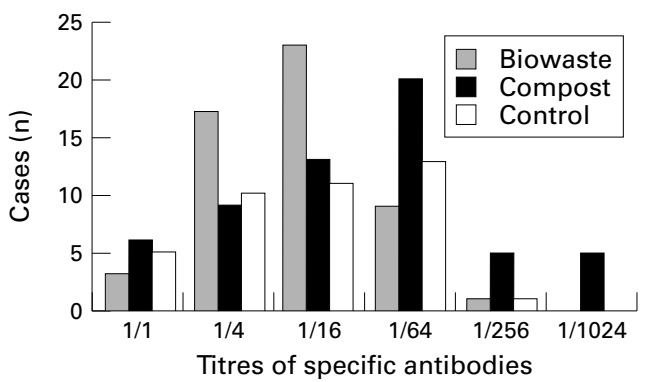

Figure 1 Specific IgG antibody concentrations to Aspergillus fumigatus split by groups of workers and controls, $p=0.02$ with the Kruskal Wallis test. 

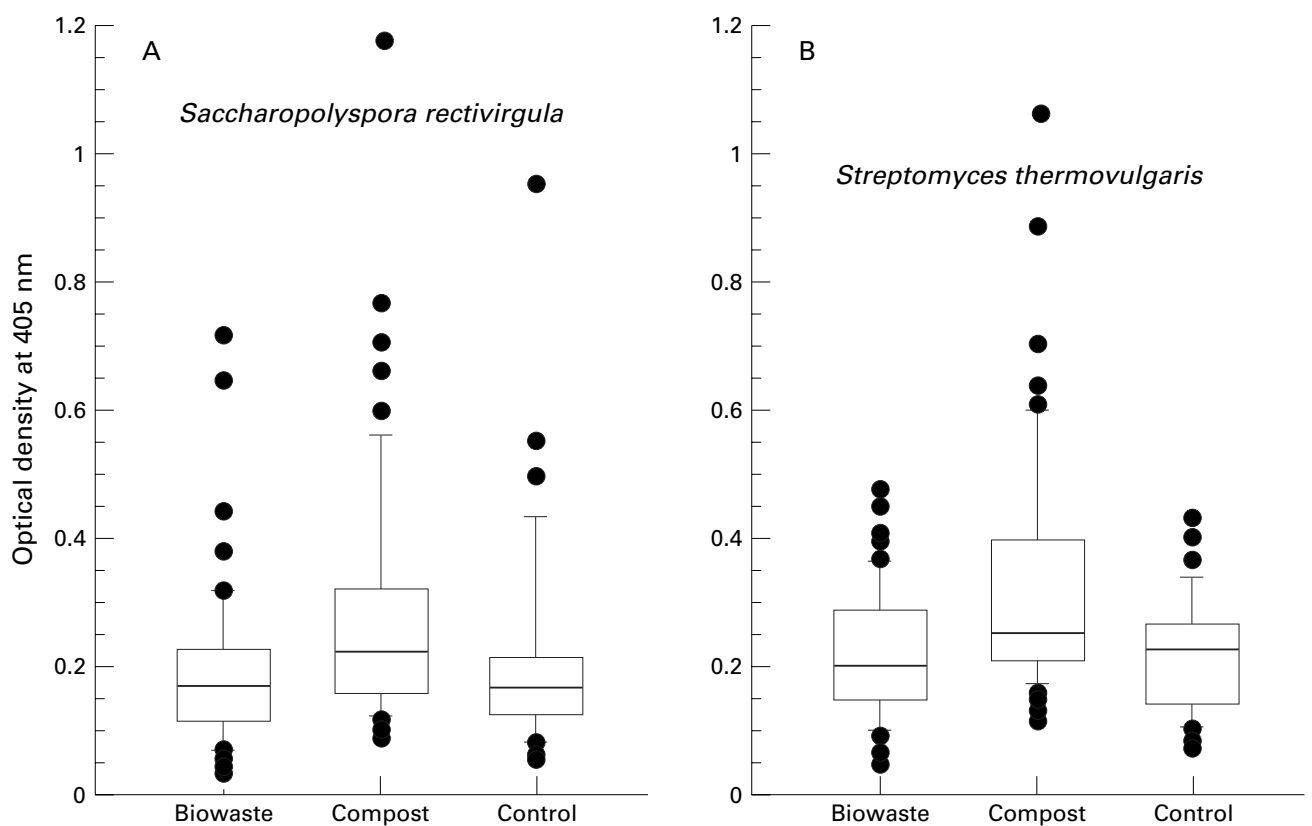

Figure 2 Specific IgG antibody concentrations to actinomycetes split by groups of workers and controls, $p<0.001$ with the Kruskal-Wallis test.

exposure to bioaerosols. A significant association was also found between the duration of employment of the compost workers and the number of increased IgG concentrations (fig 3). No such association was found in the biowaste collectors.

\section{Discussion}

Up to now, published information on health risks of compost workers is scarce. In 1984, Clark et al diagnosed infections and mucosal irritation in workers who composted sludge of waste water treatment facilities. ${ }^{41}$ The exposed workers reported burning eyes and skin irritation significantly more often than workers without exposure to bioaerosols. In the physical

Table 5 Comparison of the diseases of the compost workers with increased specific IgG concentrations against actinomycetes and moulds (antibody concentrations were considered to be increased when optical density exceeded $3 S D$ of the mean of the control subjects for actinomycetes and for fungi at titres $\geqslant 1: 1024$ )

\begin{tabular}{|c|c|c|c|c|c|}
\hline & \multicolumn{5}{|c|}{ Subjects with increased specific IgG antibodies to } \\
\hline & Actinomycetes & Moulds & Both & Total & $p$ Value \\
\hline Diseases of airways $(n=14)$ & 5 & 1 & 2 & 8 & 0.02 \\
\hline Diseases of skin $(n=8)$ & 2 & 1 & 2 & 5 & 0.03 \\
\hline Both $(n=22)$ & 7 & 2 & 4 & 13 & 0.004 \\
\hline No diseases $(n=36)$ & 3 & 3 & 1 & 7 & \\
\hline \multicolumn{6}{|c|}{$\begin{array}{l}\mathrm{p} \text { Values were calculated from the total numbers of compost workers with increased specific IgC } \\
\text { antibodies } v \text { healthy compost workers with Fisher's exact test, two sided. }\end{array}$} \\
\hline \multicolumn{6}{|c|}{$\begin{array}{l}\text { Table } 6 \text { Comparison of the diseases of the compost workers with increased specific IgG } \\
\text { concentrations against actinomycetes and moulds after correction for confounding bioaerosol } \\
\text { exposures (antibody concentrations were considered to be increased when optical density } \\
\text { exceeded } 3 \text { SD of the mean of the control subjects for actinomycetes and for fungi at titres } \\
\geqslant 1: 1024 \text { ) }\end{array}$} \\
\hline & \multicolumn{5}{|c|}{ Subjects with increased specific IgG antibodies to } \\
\hline & Actinomycetes & Moulds & Both & Total & $p$ Value \\
\hline Diseases of airways $(n=11)$ & 3 & 0 & 2 & 5 & 0.03 \\
\hline Diseases of skin $(n=7)$ & 2 & 1 & 1 & 4 & 0.02 \\
\hline Both $(n=18)$ & 5 & 1 & 3 & 9 & 0.006 \\
\hline No diseases $(n=33)$ & 2 & 2 & 0 & 4 & \\
\hline
\end{tabular}

$\mathrm{p}$ Values are calculated from the total numbers of compost workers with increased specific IgG antibodies $v$ healthy compost workers with Fisher's exact test, two sided. examination, a significantly higher prevalence of diseases of the skin, mainly due to infections, and of the upper airways was diagnosed in the exposed workers. Four exposed workers had an ear infection. One of them had chronic otitis media, requiring a tympanomastoidectomy. Aspergillus niger was isolated from the effluent of the ear. The same worker had signs of a diffuse interstitial lung disease on his chest $x$ ray film. A very similar pattern of symptoms and diseases was found in the biowaste composting workers of this study, except for signs of interstitial lung disease.

Danish waste workers reported a significantly higher prevalence of symptoms of mucous membrane irritation and organic dust

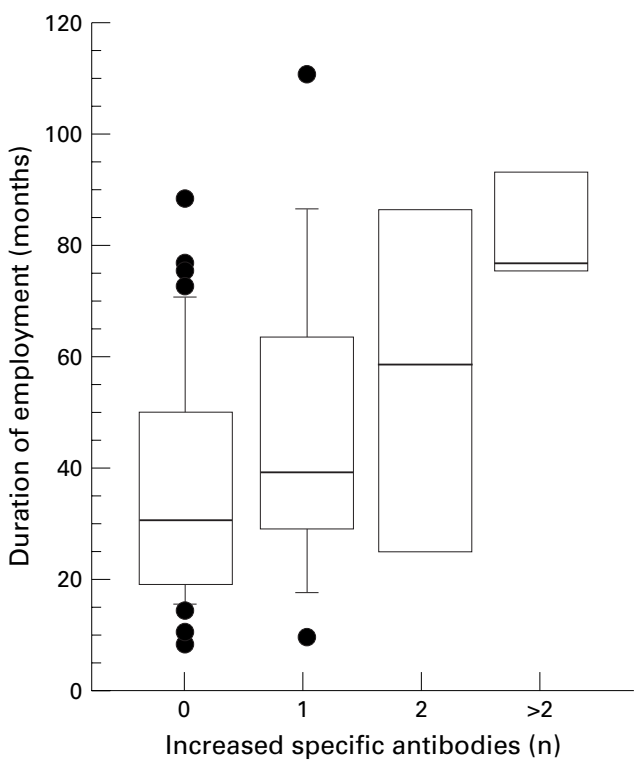

Figure 3 Association of the duration of the employment of the compost workers with the number of increased specific I $G$ antibody concentrations; $p=0.03$ with the Kruskal Wallis test. 
toxic syndrome due to sorting rubbish compared with workers employed in facilities supplying drinking water. ${ }^{22}$ Eight compost workers included in this study reported chronic bronchitis, chronic dry cough, and irritation of the nose. However, the analysis of health complaints of this group gave no significant results, probably due to few subjects. Symptoms of mucous membrane irritation were also reported in waste collectors in Sweden who handled compostable waste and household waste that was not separated. ${ }^{42}$

In 1980, Lundholm and Rylander reported nausea, headache, and diarrhoea in four of 11 workers in an experimental compost plant. ${ }^{43}$ Nausea was also reported by four compost workers in this study, although this number of symptoms was not significantly higher than in the control group. In an investigation based on 1747 answered questionnaires, Danish waste collectors reported significantly higher prevalences of gastrointestinal symptoms - such as nausea and diarrhoea. ${ }^{44}$ Gastrointestinal symptoms - such as nausea, vomiting, and particularly diarrhoea-were also found in the two Scandinavian studies. ${ }^{22}{ }^{42}$ However, it remained unclear if these symptoms had been caused by infections, toxic compounds, or other adverse effects at the workplaces. Nausea was attributed by some workers to the smell of rotten waste. ${ }^{44} \mathrm{~A}$ bad smell was also reported by some biowaste collectors in this study, but was not associated with nausea.

Chronic impairment of pulmonary function due to exposure to bioaerosols was found in workers of the grain processing and animal feed industries and was associated with high endotoxin and total dust concentrations. ${ }^{18}$ As in our study, similar results have not yet been found in waste handling workers. ${ }^{202}{ }^{22}$ By contrast, Swedish waste collectors had a significantly higher forced expired volume in 1 second than controls. ${ }^{42}$ This was interpreted as a healthy worker effect.

The significantly lower prevalence of allergic rhinitis in compost workers than in biowaste collectors and control subjects indicates a selection bias (healthy worker effect) in this study as well. Sigsgaard et al reported underrepresentation of asthma among garbage handling workers. ${ }^{22}$ Subjects with atopic diseases were also underrepresented in studies on workers exposed to organic dust in the grain processing and animal feed industries ${ }^{18}$ and in the potato processing industry. ${ }^{45}$ Therefore, health risks due to exposure to bioaerosols are likely to be underestimated at these workplaces.

The implemented IIFT and ELISA techniques are very sensitive methods of detecting specific antibodies, as IgG concentrations of people exposed solely environmentally (controls) can even be measured. ${ }^{46}$ High exposure to organic dust in workplaces where compost is handled is associated with increased concentrations of specific IgG antibodies to actinomycetes and moulds. Nevertheless, cross reactivity of fungus antigens is likely to occur in the aspergillus group, as titres of Aspergillus sydowii, which was rarely identified at compost work- places, were also significantly increased in compost workers, and one worker who had titres of 1:1024 for three other Aspergillus species, had a titre of 1:1024 for Aspergillus sydowii.

Specific IgG antibodies are involved in the aetiology of extrinsic allergic alveolitis, but so far none of the investigated subjects with increased specific IgG concentrations in this study had symptoms of that disease. The significant association of the diagnosed diseases of the airways and the skin in the compost workers with increased specific antibody concentrations is probably not cause dependent, but both effects are due to the high exposure to bioaerosols of the workers.

The increased concentrations of specific antibodies to fungi and actinomycetes reflect the results of the high exposures at compost workplaces measured in previous studies (table 1). The absence of significant increases of specific IgG antibodies in the biowaste collectors can be explained by the substantially lower exposures to bioaerosols. However, this result may also be due to the significantly shorter duration of employment, as a association between increased specific IgG concentrations and duration of employment was found in compost workers. Thus we suggest the further evaluation of these variables as immunological markers of exposure to bioaerosols. Whether workers with increased antibody concentrations are at risk for extrinsic allergic alveolitis should be investigated in longitudinal studies.

We thank the following laboratory technicians for their excellent assistance: Gesa Homann, Martina Lange, Anke Seeckts, Petra Tucholla, Jutta Utermöhle.

1 Poulsen OM, Breum NO, Ebbehoj N, et al. Sorting and recycling of domestic waste. Review of occupational health problems and their possible causes. Sci Total Environ 1995;168:33-56.

2 Schmidt B, Philipp W. Emission von Bakterien in Kompostwerken und anderen müllverarbeitenden Anlagen. Forum Städte-Hygiene 1994;45:331-7.

3 Göttlich E, Erkrath K, Engesser KH, et al. Emission von Pilzsporen in Müllverarbeitungsanlagen. Forum StädtePygiene 1994;45:321-5.

4 Kutzner HJ, Kempf A. Emission von ActinomycetenSporen in Kompostwerken und anderen müllverarbeiSporen in Kompostwerken und anderen mullverarbe

tenden Anlagen, Forum Städte-Hygiene 1994;45:326-30.
5 Pfirmann A, Vanden Bossche G. Emission von Viren in Kompostwerken und anderen müllverarbeitenden Betrieben. Forum Städte-Hygiene 1994;45:338-45.

6 Nielsen EM, Breum NO, Nielsen BH, et al. Bioaerosol exposure in waste collection: a comparative study on the significance of collection equipment, type of waste and seasonal variation. Ann Occup Hyg 1997;41:325-44.

7 Martens W, Fessel A, Haumacher R, et al. Untersuchungen zu Keimemissionen bei der Sammlung von Restmüll, Bioabfällen und Papier. In: Böhm R, Unselm J, eds. DVG-Fachtagung Gesundheitliche Risiken durch Keimemissionen bei Einsammeln, Transport und Verarbeitung häuslicher Abfälle. Giessen: DVG, 1998:29-74.

8 Beaumont F, Kauffman HF, van der Mark TH, et al. Volumetric aerobiological survey of conidial fungi in the north metric aerobiological survey of conidial fungi in the north meteorological variables. Allergy 1985;40:173-80.

9 Karlsson K, Malmberg P. Characterization of exposure to molds and actinomycetes in agricultural dusts by scanning electron microscopy, fluorescence microscopy and the culture method. Scand F Work Environ Health 1989;15:353-9.

10 Rylander R. Organic dusts: from knowledge to prevention. Scand $\mathcal{F}$ Work Environ Health 1994;20(special): 116-22.

11 Richerson HB. Unifying concepts underlying the effects of organic dust exposures. Am F Ind Med 1990;17:139-42.

12 do Pico GA. Hazardous exposure and lung disease among farm workers. Clin Chest Med 1992;13:311-28.

13 Lacey J, Crook B. Fungal and actinomycete spores as pollutants of the workplace and occupational allergens. Ann Occup Hyg 1988;32:515-33.

14 Rylander R. Lung diseases caused by organic dusts in the farm environment. Am f Ind Med 1986;10:221-7.

15 Rylander R, Bake B, Fischer JJ, et al. Pulmonary function and symptoms after inhalation of endotoxin. Am Rev Respir Dis 1989;140:981-6. 
16 Donham K, Haglind P, Peterson Y, et al. Environmental and health studies of farm workers in Swedish swine confinement buildings. Br f Ind Med 1989;46:31-7.

17 Simpson JCG, Niven RM, Pickering CAC, et al. Prevalence and predictors of work related respiratory symptoms in workers exposed to organic dusts. Occup Environ Med 1998;55:668-72.

18 Post W, Heederik D, Houba R. Decline in lung function related to exposure and selection processes among worker in the grain processing and animal feed industry. Occup Environ Med 1998;55:349-55.

19 Gladding TL, Coggins PC. Exposure to microorganisms and health effects of working in UK materials recovery facilities: a preliminary report. Annals of Agricultural and Environmental Medicine 1997;4:137-41.

20 Grüner C, Bittighofer PM, Roller A, et al. Gesundheitliche Belastung, Beanspruchung und Beschwerden bei Wertstoffsortierern und Deponie-Beschäftigten durch Mikroorganismen. In: Hallier E, Bünger J, eds. Dokumentationsband ganismen. In: Hallier E, Bünger J, eds. Dokumentationsband der 37. Fahrestagung der Deutschen Gesellschaft für Arbeitsmedizin und

21 Gelberg KH. Health study of New York city department of sanitation landfill employees. F Occup Environ Med 1997;11:1103-10.

22 Malmros P, Sigsgaard T, Bach B. Occupational health problems due to garbage sorting. Waste Management Research 1992;10:227-34

23 Vincken W, Roels P. Hypersensitivity pneumonitis due to Aspergillus fumigatus in compost. Thorax 1984;39:74-5.

24 Weber S, Kullman G, Petsonk E, et al. Organic dust exposures from compost handling: case presentation and respiratory exposure assessment. Am f Ind Med 1993;24: 365-74.

25 Brown JE, Masood D, Couser JI, et al. Hypersenitivity pneumonitis from residential composting: residential com-
poster's lung. Ann Allergy Asthma Immunol 1995;74:45-7.

26 Allmers H, Huber H, Baur X. Bronchopulmonale Schimmelpilz-Allergie eines Müllwerkers. Arbeitsmedizin Sozialmedizin Umweltmedizin 1997;32:64-7.

27 Bamdad S. Enzyme-linked immunosorbent assay (ELISA) for IgG antibodies in farmer's lung disease. Clin Allergy 1980;11:161-71.

28 Baur X, Richter G, Pethran A, et al. Increased prevalence of IgG-induced sensitization and hypersensitivity pneumonitis (humidifier lung) in non-smokers exposed to aerosols of a contaminated air conditioner. Respiration 1992;59:21114.

29 Anderson K, Watt AD, Sinclair D, et al. Climate, intermittent humidification, and humidifier fever. $\mathrm{Br} \mathcal{F}$ Ind Med 1989,46:671-4.

30 Ojanen T. Class specific antibodies in serodiagnosis of farmer's lung. Br F Ind Med 1992,49:332-6.

31 Bünger J, Bittighofer PM, Grüner C, et al. Spezifische Antikörper gegen Actinomyceten als Biomarker der Exposition in Abfallverwertungsanlagen. In: Borsch-Galetke E Struwe F, eds. Dokumentationsband der 37. Fahrestagung der Deutschen Gesellschaft für Arbeitsmedizin und

32 Centers for Disease Control and Prevention (CDC). International classification of diseases, $9^{\text {th }}$ revision, clinical modification. Available from URL: http://www.cdc.gov./ nchswww/about/otheract/icd9/abticd.htm.

33 Stalder K, Verkoyen C, eds. Gesundheitsrisiken bei der Entsorgung kommunaler Abfälle. Göttingen: Verlag Die Werkstatt, 1994.

34 Bünger J, Müller M, Stalder $\mathrm{K}$, et al. Immunological biomonitoring in the assessment of exposure to airborne fungi from waste handling. In: Johanning E, ed. Bioaerosols, fungi and mycotoxins: health effects, assessment, prevention and control. Albany, NY, US: Eastern New York Occupational and Environmental Health Center, 1999:112-18.

35 Parratt D, Peel JA. A fluorescent antibody test in the diagnosis of farmer's lung. F Clin Pathol 1972;25:846-9.

36 Zwick H, Popp W, Braun O, et al. Personal spore sampling and indirect immunofluorescent test for exploration of hypersensitivity pneumonitis due to mould spores. Allergy 1991;46:277-83.

37 Engvall E, Perlmann P. Enzyme linked immunosorbent assay (ELISA). Quantitative assay of IgG. Immunochemistry 1971;8:871-4

38 Marx JJ, Gray RL. Comparison of enzyme-linked immunosorbent assay and double immunodiffusion test for the detection and quantification of antibodies in farmer's lung disease. F Allergy Clin Immunol 1982,70:109-13.

39 Edwards $\mathrm{JH}$. The double dialysis method of producing farmer's lung antigens. F Lab Clin Med 1972;79:683-8.

40 Treuhaft MW, Roberts RC, Hackbarth C, et al. Characterization of synthetic medium antigens of Micropolyspora faeni and Thermoactinomyces candidus. F Allergy Clin Immunol 1981;67:375-87.

41 Clark CS, Biornson HS, Schwartz-Fulton J, et al. Biological health risks associated with the composting of wastewater treatment plant sludge. Fournal of the Water Pollution Control treatment plant sludge. Fournal

42 Thorn J, Beijer L, Rylander R. Airways inflammation and glucan exposure among household waste collectors. $A m \mathcal{F}$ 463-70

43 Lundholm M, Rylander R. Occupational symptoms among compost workers. F Occup Med 1980;22:256-7.

44 Ivens UI, Ebbehoj N, Poulsen OM, et al. Season, equipment, and job function related to gastrointestinal problems in waste collectors. Occup Environ Med 1997;54: $861-7$.

45 Zock JP, Heederik D, Doekes G. Evaluation of chronic respiratory effects in the potato processing industry: indications of a healthy worker effect? Occup Environ Med 1998; 55:823-7

46 Stalder K, Bünger J. Health risks from facultative pathogenic microorganisms in garbage handling: aspects of environmental and occupational medicine. Forum StädteHygiene 1996;47:142-6.

\section{Correspondence and editorials}

Occupational and Environmental Medicine welcomes correspondence relating to any of the material appearing in the journal. Results from preliminary or small scale studies may also be published in the correspondence column if this seems appropriate. Letters should be not more than 500 words in length and contain a minimum of references. Tables and figures should be kept to an absolute minimum. Letters are accepted on the understanding that they be subject to editorial revision and shortening.

The journal also publishes editorials which are normally specially commissioned. The Editor welcomes suggestions regarding suitable topics; those wishing to submit an editorial, however, should do so only after discussion with the Editor. 